\title{
Steer Diets in Southeastern Colorado
}

\section{RELDON F. BECK}

Highlight: Hereford steers having continuous access to seeded, native, and old field pastures selected over $96 \%$ of their diet from six species of grasses and forbs. Changes in species preferences due to availability and maturation of plants caused shifts in summer grazing use made on the different pastures. A grazing proposal based on diets and the periods when steers preferred different forage species is to use old field pastures from mid-spring to early summer, seeded pastures in mid-summer, and native pastures in late summer through fall.

Cattle production in southcastern Colorado is an economically important industry. Gross income from the sale of cattle grown on pastures and rangelands has increased annually for the past decades (Guellow and Jones, 1961). Lands on which the grazing industry depends support three vegetation types: native, seeded, and old fields. Much of the land that was cultivated from the 1880's to the 1930's was abandoned after the drouth and economic depression of the latter decade. Thousands of hectares of this formerly cultivated land have been used for grazing since abandonment (Underwood, 1944; U.S. Bureau of the Census, 1972). Part of this former cropland is in various successional stages (old field pastures) while the remainder has been reseeded with native grasses. Other lands not cultivated have been used continuously for grazing since the area was first settled.

The purpose of this study was: (1) to determine dietary habits of grazing steers having access to either seeded, native or old field pastures during the growing season; and (2) to propose a grazing scheme from the dietary information which will allow more efficient use of available forage.

\section{Study Area and Procedures}

Research was conducted on three 16-ha pastures on the Southeastern Colorado Branch Experiment Station, located 16 $\mathrm{km}$ southwest of Springfield, Baca County, Colorado. Data were collected from May 1 to October 15, 1967, and from July 1 to October 15,1968 . Each pasture represented one of the three vegetation types commonly found in the area: seeded, native, and old field. The seeded pasture in this study had been reseeded to sideoats grama (Bouteloua curtipendula) and blue grama (B. gracilis) in 1961. The three pastures were adjacent with no intervening fences. Eight yearling Hereford steers used for observations were free to graze in all pastures. Stocking rate was 2.5 acres per steer month, which allowed light to moderate use of the pastures.

The general area is characterized by climatic and biological factors typical of the Central and Southern Great Plains

The author is assistant professor, Department of Animal, Range and Wildlife Sciences, New Mexico State University, Las Cruces. Gratitude is expressed to the staff of the Department of Range Science, Colorado State University, and to personnel of the Southeastern Branch Experiment Station, Springfield, Colorado, for help during this research.

Manuscript received June 17, 1974. regions. The climate is a semiarid, temperate, continental type; irregular rainfall patterns characterize the seasons and the year. The average annual precipitation for the past 12 years from the U.S. Weather Station located $5 \mathrm{~km}$ northeast of the study pastures (station headquarters) is $37 \mathrm{~cm}$. About $80 \%$ of the annual precipitation falls during the growing season. Winter snows are infrequent and contribute little to soil moisture. Evaporation from a freewater surface averages $170 \mathrm{~cm}$ from April 1 to October 31 (Table 1). The average temperature since 1957 is $11.6^{\circ} \mathrm{C}$ with an annual maximum near $38^{\circ} \mathrm{C}$ and the minimum near $-22^{\circ} \mathrm{C}$. The period between frosts is approximately April 15 to September 30 . However, the length of the growing season is dependent upon moisture availability rather than temperature.

During the 1967 and 1968 growing season, the plant composition in each pasture was determined by a variation of the step-point method proposed by Evans and Love (1967). Sampling was in mid-growing season and nearly all plant species growing on the pastures were detected. Most plants growing on the pastures were perennials, and little difference in composition was noted between years. Therefore, composition data for each pasture were averaged for both years.

Steer diets were determined by counting the number of bites a steer ate of each plant species. Steers were observed almost every morning and evening on 5 continuous days every other week throughout the two summers. Generally, only one steer was observed for any observation period, and all steers were observed at least once in a sampling week. Observation periods usually lasted 75 minutes. The morning period started a few minutes after sunrise, and the evening period was completed while a few minutes of sunlight remained.

Steers were observed from a pickup truck which did not visibly influence the movements of the steers as they grazed. Identification of plant species being eaten was aided by using 7 $X 35 \mathrm{~mm}$ binoculars. To aid identification of plants being grazed, the pastures were mowed to a 4-inch stubble each

Table 1. Precipitation $(\mathrm{cm})$ and evaporation $(\mathrm{cm})$ data for Southeastern Colorado Branch Experiment Station, Springfield, for the growing seasons of 1967 and 1968.

\begin{tabular}{lrrrrr}
\hline & \multicolumn{2}{c}{$1967^{1}$} & & \multicolumn{2}{c}{$1968^{2}$} \\
\cline { 2 - 3 } \cline { 5 - 6 } Months & Precip. & Evap. & & Precip. & Evap. \\
\hline April & 2.3 & 28.0 & & 1.0 & 20.9 \\
May & 2.3 & 24.1 & & 5.8 & 22.6 \\
June & 12.2 & 24.2 & & 2.3 & 35.3 \\
July & 4.7 & 25.0 & & 10.1 & 32.2 \\
August & 5.2 & 24.0 & & 2.8 & 27.1 \\
September & 2.8 & 19.5 & & 0.5 & 24.2 \\
October & 0.4 & 18.9 & & 0.2 & 19.3 \\
Total & 29.9 & 163.7 & & 22.7 & 175.1 \\
\hline
\end{tabular}

\footnotetext{
${ }^{1}$ Precipitation $=0.18$

Evaporation

${ }^{2}$ Precipitation $=0.13$

Evaporation
} 
spring to remove old growth. Removal of old growth also allowed steers to graze more selectively.

The bites selected from each plant species were recorded as some fraction of a bite (air-dry basis) of sand dropseed (Sporobolus cryptandrus). This comparison was made for each observation week by handplucking samples of plant species most abundant in steer diets. The mean dry weight for a handpluck of each plant species was calculated as a fraction of the mean dry weight for a handpluck of sand dropseed. This produced constants which were multiplied times the number of bites eaten of each respective plant species. This computation allowed a comparison of bites eaten from various sized plant species. The percent that each plant species contributed to diets was averaged for all three pastures for each month of observations. Diets for both summers, being very similar on a month-to-month basis, were averaged.

Grazing time on each pasture was recorded during observation periods. The percent of time steers spent grazing on each pasture was similar for both years, and was averaged for both years into 2-month segments.

\section{Results and Discussion}

\section{Plant Composition of Pastures}

Each pasture had two perennial grasses which comprised at least $65 \%$ of available herbage (Table 2). The two most common grasses on the seeded pasture were sideoats grama and blue grama. The most frequent grasses on the native pasture were blue grama and buffalograss (Buchloe dactyloides); on the old field pasture sand dropseed and buffalograss were most abundant. Other grasses besides blue and sideoats grama found on the old field pasture comprising $2 \%$ to $12 \%$ of the vegetation were three-awns (Aristida spp.), western wheatgrass (Agropyron smithii), and tumblegrass (Schedonnardus paniculatus). Kochia (Kochia scoparia) and lambsquarter (Chenopodium album) were the most common forbs present on all three pastures. Other forbs were present in trace amounts and were occasionally eaten by the steers. Common forbs included within this group were slimflower scurfpea (Psoralea tenuiflora), scarlet glovemallow (Sphaeralcea coccinea), fetid marigold (Dyssodia papposa), common sunflower (Helianthus annua), and Russian thistle (Salsola kali).

Aerial plant cover on all pastures averaged over $80 \%$ with the seeded pasture having slightly less than the other two. Most plant species were perennial in nature, thus, only slight variations were found in species composition between years.

\section{Diets}

Steer diets in southeastern Colorado were comprised of nearly all plants present on sccded, native, and old field
Table 2. Average botanical composition (\%) by step-point frequency on three pastures in 1967 and 1968.

\begin{tabular}{lrrrr}
\hline \hline & \multicolumn{4}{c}{ Pastures } \\
\cline { 3 - 5 } Specics & Seeded & Native & Old field & Average \\
\hline Grasses & 13.2 & 37.6 & 3.4 & 18.1 \\
$\quad$ Blue grama & 5.2 & 41.0 & 27.4 & 24.5 \\
Buffalograss & 4.4 & 8.4 & 38.2 & 17.0 \\
Sand dropseed & 65.3 & 1.2 & 2.2 & 22.9 \\
Sideoats grama & & & & \\
Forbs & 4.3 & 3.9 & 5.4 & 4.5 \\
$\quad$ Kochia & 0.4 & 1.8 & 1.4 & 1.2 \\
$\quad$ Lambsquarter & 7.2 & 6.1 & 22.0 & 11.8 \\
All others & & & & \\
\hline
\end{tabular}

pastures. This agrees with findings of others, including Springfield and Reynolds (1951), who found cattle selected a wide variety of plants when given free choice. Steers ate the more common plants in both summers: blue grama, buffalograss, sand dropseed, sideoats grama, kochia, and lambsquarter (Table 3). Dominant grasses on each pasture made large contribution to steer diets although seasonal changes in preference were evident. Sand dropseed was important in May and June and then declined during the remainder of the season, although still dominant in July and August (Table 3). Blue grama made up 20\% to $25 \%$ of the diets until late season when it became dominant. Sideoats grama and sand dropseed are similar in appearance and growth form, and both initiate growth earlier than either blue grama or buffalograss. Since steers appeared to seek green forage after eating dry winter feed, sand dropseed and sideoats grama contributed considerably to spring diets. Sand dropseed was preferred over sideoats grama by the steers, even though more of the latter was available on all 3 pastures. After blue grama and buffalograss started growing, the steers ate more of these two species, possibly because the steers preferred new green growth, or becausc sand dropseed and sideoats grama were becoming less palatable due to maturation.

Buffalograss consumption was not related to availability (Fig. 1). Dwyer (1961) observed that cattle ate very little buffalograss on "shallow sites" in northern Oklahoma even though it comprised over $57 \%$ of the vegetation on this site. In the present study, buffalograss contributed little to diets throughout 1967 and in early 1968, but in October, 1968, over $45 \%$ of forage selected from native pasture was buffalograss. The reason for the difference between the 2 years was that luxuriant forage of many species was available to the steers in 1967, whereas in 1968 the vegetation was drier and, during the latter part of the season, the lower half of buffalograss plants was essentially the only green forage

Table 3. Average botanical composition (\%) of diets of steers having free access to seeded, native, and old field pastures in 1967 and 1968.

\begin{tabular}{|c|c|c|c|c|c|c|c|}
\hline \multirow[b]{2}{*}{ Species } & \multicolumn{6}{|c|}{ Month } & \multirow[b]{2}{*}{ Average } \\
\hline & May $^{1}$ & June $^{1}$ & July & August & September & October & \\
\hline \multicolumn{8}{|l|}{ Grasses } \\
\hline Blue grama & 26.0 & 19.9 & 26.3 & 17.3 & 36.0 & 46.6 & 29.1 \\
\hline Buffalograss & 8.8 & 5.1 & 3.2 & 1.1 & 6.0 & 18.2 & 8.1 \\
\hline Sand dropseed & 37.3 & 48.2 & 29.1 & 34.1 & 22.7 & 11.7 & 31.2 \\
\hline Sideoats grama & 23.0 & 17.7 & 18.9 & 17.2 & 4.5 & 6.5 & 16.4 \\
\hline \multicolumn{8}{|l|}{ Forbs } \\
\hline Kochia & 1.4 & 7.4 & 19.7 & 28.3 & 15.5 & 10.6 & 10.2 \\
\hline Lambsquarter & - & 1.0 & 1.5 & 0.5 & 14.2 & 4.9 & 2.9 \\
\hline All others & 3.5 & 0.7 & 1.3 & 1.6 & 1.1 & 1.6 & 2.1 \\
\hline
\end{tabular}

\footnotetext{
1967 data only.
} 


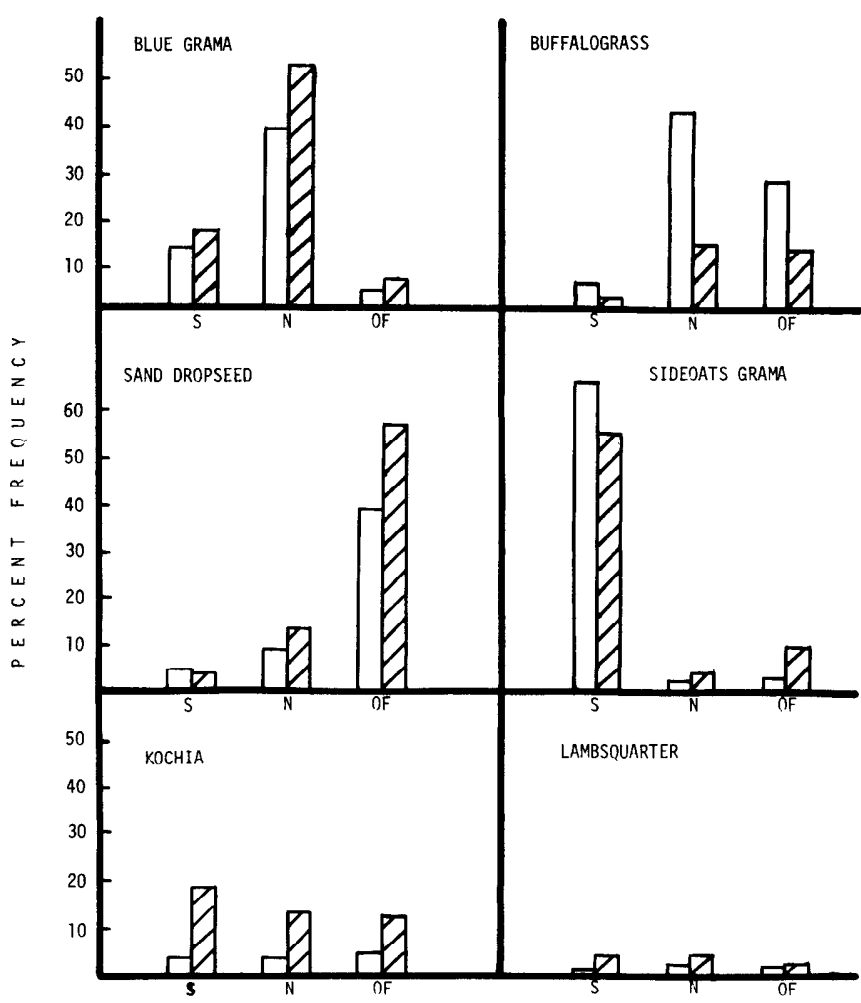

Fig. 1. Frequency of six key forage species in steers' diets (crosshatch bar) and that available on seeded (S), native (N), and old field (OF) pastures (open bar).

available. Buffalograss does not appear to be an important forage plant during the growing season in this area. However, ranchers who live in the area report that it is readily eaten by cattle during the fall and winter.

Forbs were important in steer diets on all three pastures. Kochia and lambsquarter were the most abundant forbs and were eaten readily when available. Kochia became important in the diet when it attained 8 to $10 \mathrm{~cm}$ in height, which usually occurred about 1 month after sufficient soil moisture was available for growth. Thereafter, plants of kochia were sought and eaten with relish during all stages of growth on all three pastures.

In 1967 lambsquarter was eaten while immature, and again after seed maturity. Steers would wrap their tongues around the lambsquarter plants and pull upward, taking in seed and any leaves present. In 1968 lambsquarter was scarce and never comprised over $2 \%$ of the diets. According to Hoehne et al. (1968), luxuriant growth of lambsquarter depends on average or above-average rainfall during the growing season in western Nebraska. During this study, precipitation in 1967 was near the long-time average, and in 1968 it was $13 \mathrm{~cm}$ below the long-time average. The shortage of moisture available in June, 1968 , may have been partially responsible for the scarcity of lambsquarter, and may explain why it was not abundant in steer diets that year. The steers ate many other forbs, including Russian thistle, fetid marigold, common sunflower, scarlet globemallow, and slimflower scurfpea, but not in a regular pattern nor in any large quantities.

Steer preference for plant species was affected by phenological stage. Nearly all species of plants were eaten while young and growing. When flowering started, some species were no longer eaten while others became preferred. Steers ate the culms and inflorescences of blue grama, buffalograss, sand dropseed, and sideoats grama when these were encountered, but generally grazed on regrowth from plants of grass grazed previously. After grasses matured, steers tried to find plants that were partially green. In contrast, when forage was lush, steers appeared to purposely select dry, mature plants after eating a considerable quantity of lush forage. When dry plants were wet from either dew or rain, the steers did not exhibit any preferences among the plants they selected to eat. Similar observations have been reported by Springfield and Reynolds (1951) and Dwyer (1961).

Time spent grazing on each pasture was quite similar for both years. Time spent on the old field declined from $50 \%$ in May and June to $24 \%$ in September and October (Fig. 2). Grazing time on the native pasture increased as the season progressed, which correlates directly with seasonal changes in steers diets. Animals never grazed seeded pasture as long as the other pastures. The seeded pasture was farthest from water, being $400 \mathrm{~m}$ away, but distance from water was not regarded as the reason for the lesser amount of grazing on this area. Steers may have slighted this pasture because of the predominance of sideoats grama and the lack of other preferred plants. Most sideoats grama present was yellow-green in color, and steers appeared to prefer dark-green plants. All the sideoats grama plants on the native and old field pastures were dark green and were highly preferred by the stecrs. Stccrs utilized yellow-green plants on the seeded pasture only during the last few weeks of both summer grazing seasons. Dwyer et al. (1964) reported that cattle did not utilize yellow plants of sideoats grama and attributed color difference between plants to the differing amounts of soil nitrogen.

\section{Grazing Program}

Results of this study indicate that successful grazing programs for this area should be based only on perennial plants; any annual plants are a luxury to cattle diets. This is exemplified by the amount of lambsquarter available as forage between the two summers. Based on the steer's selection of predominant perennial grasses (Table 3 ) and time spent grazing on a particular pasture (Fig. 2), the following proposal should bencfit cattlc and pastures:

Old field pastures-late April to early July

Seeded pastures-early July to mid-late August

Native pastures-late August to late fall.

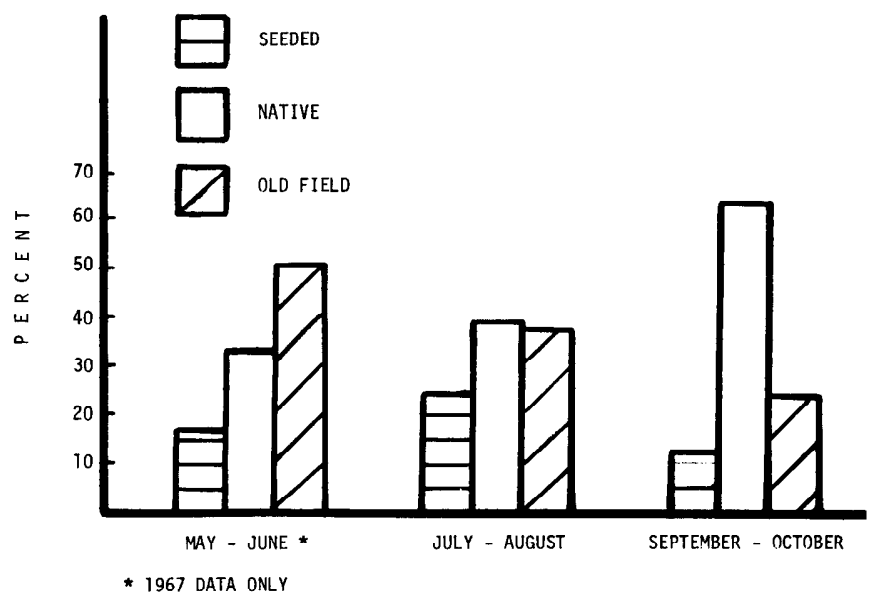

Fig. 2. Mean percent grazing time steers spent on either seeded, native, or old field pastures in 1967 and 1968. 
This proposal indicates when cattle would most likely utilize forage growing on particular pastures. For ranchers having varying amounts of the three pasture types, the proposed scheme can only serve as a guide, and adjustments would be necessary for each rancher's particular situation.

Where all three types are in a large unit and in fairly equal proportions, fencing may not bc necessary. No particular species should be over utilized when the unit is stocked properly, and seasonal preferences would naturally shift cattle from one area to another. However, if proportions of the three types are unequal, the smallest type may be over utilized when its most abundant species is highly preferred. This situation was observed on Branch Station pastures other than those used in this study.

Vegetation composition on old field and native pastures are fairly similar in this general area. However, some seeded pastures have been planted to grasses other than sideoats grama, and for these pastures the above grazing scheme and many related statements may not hold true.

\section{Conclusions}

1. Steers given free-choice to many plant species are selective, and their diets change during a summer grazing season.

2. Sand dropseed, an early plant in secondary succession in southeastern Colorado, is preferred by steers. Land owners in this area should consider managing part of their grazing lands for sand dropseed for use in late spring and early summer.

3. Sideoats grama should be used sparingly as a species with which to reseed pastures in southeastern Colorado. It tends to exhibit nitrogen deficiency more readily than other native species, which may partly explain its lack of palatability. More research is needed to improve established sideoats grama stands and to find other species with which to reseed in this area.

4. Forbs are important in livestock diets and should be fully utilized when available; however, because many are annuals and their presence fluxuates with erratic rainfall, no grazing system should be dependent upon them.

\section{Literature Cited}

Dwyer, D. D. 1961. Activities and grazing preferences of cows with calves in northern Osage County, Oklahoma. Oklahoma State Univ. Exp. Sta. Bull. B-588. 61 p.

Dwyer, D. D., P. L. Sims, and L. S. Pope. 1964. Preferences of steers for certain native and introduced forage plants. J. Range Manage. 17:83-85.

Evans, R. A., and R. M. Love. 1957. The step-point method of sampling - a practical tool in range research. J. Range Manage. 10:208-212.

Guellow, C. N., and D. B. Jones. 1961. Colorado agricultural statistics. Colorado Dep. Agr. Bull. 1-69. 90 p.

Hoehne, O. E., D. C. Clanton, and C. L. Streeter. 1968. Chemical composition and in vitro digestibility of forbs consumed by cattle grazing native range. J. Range Manage. $21: 5-7$.

Springfield, H. W., and H. G. Reynolds. 1951. Grazing preferences of cattle for certain reseeding grasses. J. Range Manage. 4:83-87.

Underwood, J. J. 1944. Physical land conditions in the western and southeastern Baca County soil conservation districts. Soil Conservation Service, U.S. Dep. Agr. Physical I and Survey No. 30. $54 \mathrm{p}$.

U.S. Bureau of the Census. 1972. United States census of agriculture. 1969. Colorado, County Data. Vol. 1. 41-48.

\section{ELECTION RESULTS}

The 1,799 ballots cast in the 1974 election were counted on December 11. Selected by the membership to serve the Society during the next three years were:

\section{President Elect . . . . . . . . . . Bob J. Ragsdale Directors . . . . . . . . Lyman C. Linger E. H. McIlvain}

The new officers will be installed at the forthcoming Annual Meeting in Mexico City, at which time Dr. Dillard H. Gates, the current president elect, will succeed to the presidency. Dr. Ragsdale will serve as president in 1976 and the two newly elected directors will serve for the three-year term 1975-1977.

Retiring next month from the Board of Directors are Past President Martin H. Gonzalez and Directors John H. Ehrenreich and F. Robert Gartner. The very significant service rendered to the Society by these men is greatly appreciated.

Bob Ragsdale is a native Texan and currently is project leader in range science and range specialist at the Texas Agricultural Extension Service.

Lyman Linger is a rancher in Loveland, Colorado. "Pat" McIlvain is engaged in agricultural research on range forage-beef cattle management systems.

Lee Carr, Carl Fonte, Phil Sims, Al Denham, John Clark, and Jeff Burwell made up the committee responsible for counting the ballots. Ballots and tally sheets are kept on file in the Society office for a period of one year.

A proposed amendment to the SRM Bylaws passed by 1,629 votes to 112 . The revision is as follows:

Article II. Officers and Directors (changes in italics)

Section 4. Vacancies in any unexpired term, or any elective office declared vacant by the Board of Directors, shall be filled from among the Society membership $b y$ a majority vote of the Board of Directors, except that in the event of a vacancy in the office of president, the president elect shall fill the same. Any elected or appointed officer or director who fails to fulfill the responsibilities of the position may be removed from office with a two-third (2/3) majority vote of the Board of Directors meeting in regular or special session. 